\title{
Soil Quality Assessment Model for Critical Land Management Planning
}

\author{
Danang Widjajanto ${ }^{1, *}$ Uswah Hasanah $^{1}$ Bunga Elim Somba ${ }^{1}$ Salapu Pagiu ${ }^{1}$ \\ Abdul Rahman ${ }^{1}$ Rahmat Zainuddin ${ }^{1}$ Azman $^{1}$ \\ ${ }^{1}$ Soil Science Laboratory, Agriculture Faculty of Tadulako University, Palu, Indonesia \\ *Corresponding author.Email: danang1965@untad.ac.id
}

\begin{abstract}
The research purposes were to analyze land use's effect on soil physical properties and measure several lands' soil quality index in the Bulili plateau. Its conducted on three types of land use consisted of a mixed plantation, maize plantation, and forest. Soil sampling at each type of land use was carried out at five different points so that in total, there were 15 locations for soil sampling. Soil samples were taken at a depth of 0-30 cm after removing the organic layer on the soil surface. Observation of soil physical properties, including clay content, bulk density, total porosity, saturated hydraulic conductivity, organic carbon, aggregate stability, and available soil water capacity, were used to design soil quality index models. Root depth was also observed. The results showed a significant effect of land-use change on all observed soil physical properties parameters. The soil quality index for mixed plantation, maize plantation, and forest belonged to the criteria of good (0.6474), quite poor (0.3486), and good (0.6590), respectively. Land-use change caused the soil's function to conserve biological activities to decline higher than the functions of soil water redistribution and filter - buffer.
\end{abstract}

Keywords: Critical land, Land use type, Model, Soil quality index, Palu watershed

\section{INTRODUCTION}

Damage to the ecosystem in the upstream Palu watershed area harmed the emergence of flood disasters, landslides, and reduced soil water supply in the last ten years. Natural disasters that had occurred for a long period had a real psychosocial impact on the community [1]. Land-use change was the main factor affecting the physical properties of the soil. Soil erosion and sedimentation significantly affected changes in carbon stocks, soil structure, and soil water flows [2,3]. Soil bulk density, pore space volume, aggregate stability, hydraulic conductivity, and soil water holding capacity were significantly affected by changes in forest land-use types to dry land agriculture $[4,5]$.

The high dependence on soil water supply from the upstream Palu watershed caused water sources in the area to be preserved. Dryland management that considers soil-water conservation aspects needs to be designed to maintain water sources' sustainability in the area [6]. Conflict of interest in land use in the Palu watershed had led to severe land degradation [7]. To solve the complexity of problems in the land resource management system, an adaptive tool was needed. The availability of sufficient data was often the main obstacle for policy managers to formulate critical land management plans. Simplifying the system being studied into an adaptive model will make it easier for a planner to solve complex problems [8].

Previous research had developed a soil quality assessment model based on soil-climate parameters, carbon stocks, and soil pollution [9-12]. However, developing a suitable model to support critical land management in the upstream Palu watershed was still needed. Knowledge of soil physical properties affected by changes in land-use types was used as a parameter to design a model that suits the area's dryland management needs. The research objectives included: 1) determining the effect of land-use types on several soil physical properties, and 2) determining the soil quality index for mixed plantations, maize plantation, and forest land use type. 


\section{MATERIALS AND METHODS}

\subsection{Research Sites}

The research was conducted in the Bulili plateau from January to June 2020. The area was located in the upper Palu watershed, Central Sulawesi, Indonesia. The land survey was carried out on three types of land use: 1) mixed plantation (Theobroma cacao L., Leucaena leucochepala, Artocarpus heterophyllus), 2) Maize plantation, and 3) forests (Aleurites moluccana, Palaquim sp., Aquilaria malaccensis).

The soil survey was carried out on three types of land use: 1) mixed plantation (Theobroma cacao L., Leucaena leucochepala, Artocarpus heterophyllus), 2) maize plantation, and 3) forests (Aleurites moluccana, Palaquim sp., Aquilaria malaccensis).

\subsection{Sampling}

Soil samples were taken from the soil surface layer $(0-30 \mathrm{~cm})$ to analyze soil physical properties in the laboratory. The collection of disturbed and undisturbed soil samples for each land use type was carried out at five different location points. Overall, this study consisted of 15 observation points.

Disturbed soil samples were air-dried at room temperature and sieved to pass a $2 \mathrm{~mm}$ diameter sieve. Some of the physical properties of the soil observed in the study included: soil texture (pipette method), total organic carbon (Walkley-Black), content weight (gravimetric). The total porosity of the soil was determined by the equation $(1-\rho b / \rho p)$, where $\rho b$ represents bulk density and $\rho$ p represents particle density. The hydraulic conductivity of saturated soil (constant head permeameter), moisture content of field capacity, and permanent wilt point were determined by the gravimetric method (pressure plate apparatus at -33 $\mathrm{kPa}$ and $-1.500 \mathrm{kPa}$ ). The available capacity was determined by calculating the difference between the field capacity's water content and the permanent wilt point. The root depth was determined by drilling the ground in the field.

\subsection{Research Analysis}

The research data were analyzed using ANOVA, and if there was an effect of the treatment, the Duncan Multiple Range Test ( $\alpha$ : 0.05) was carried out. To determine the correlation between the soil's physical properties that affected the aggregate stability and the available soil water capacity, correlation analysis and simple linear regression was carried out.

The soil quality index was determined based on a modification of the model developed by [13]. The score was calculated by comparing the observational data from the soil indicator and the assessment function. The scores ranged from 0 for bad conditions and 1 for good conditions. The scoring could be done through interpolation or simple linear regression equations according to the range of values or data obtained. The soil quality index was determined by multiplying the weight index with the indicator score [13] with the equation (1):

Table 1. Modified soil function, weights, and indicators for assessing soil quality index

\begin{tabular}{|c|c|c|c|c|c|c|c|c|c|}
\hline \multirow{2}{*}{ Soil Function } & \multirow{2}{*}{$\begin{array}{l}\text { Weight } \\
(1)\end{array}$} & \multirow{2}{*}{ Soil Indicator } & \multirow{2}{*}{$\begin{array}{l}\text { Weight } \\
(2)\end{array}$} & \multirow{2}{*}{$\begin{array}{l}\text { Weight } \\
\text { (3) }\end{array}$} & \multirow{2}{*}{$\begin{array}{l}\text { Weight } \\
\text { Index } \\
\end{array}$} & \multicolumn{2}{|c|}{ Upper limit } & \multicolumn{2}{|c|}{ Lower Limit } \\
\hline & & & & & & $\mathrm{X} 1$ & $\mathrm{X} 1$ & $\mathrm{X} 2$ & $\mathrm{Y}_{2}$ \\
\hline \multirow{8}{*}{$\begin{array}{l}\text { Preserving } \\
\text { Biological } \\
\text { Activity }\end{array}$} & 0.4 & Rooting Medium & 0.5 & & & & & & \\
\hline & & Root Depth (cm) & & 0.60 & 0.12 & 138 & 1 & 55 & 0 \\
\hline & & Soil Bulk Density $\left(\mathrm{g} \mathrm{cm}^{-3}\right)$ & & 0.40 & 0.08 & 1.39 & 0 & 1.21 & 1 \\
\hline & & Soil Humidity & 0.5 & & & & & & \\
\hline & & Total Soil Porosity (\%) & & 0.20 & 0.04 & 46.81 & 1 & 37.10 & 0 \\
\hline & & Total Organic Carbon (\%) & & 0.35 & 0.07 & 2.88 & 1 & 1.74 & 0 \\
\hline & & Clay (\%) & & 0.15 & 0.03 & 48.26 & 1 & 31.25 & 0 \\
\hline & & $\begin{array}{l}\text { Available Soil Water Capacity } \\
(\%)\end{array}$ & & 0.30 & 0.06 & 13.54 & 1 & 11.21 & 0 \\
\hline \multirow{5}{*}{$\begin{array}{l}\text { Soil Water } \\
\text { Redistribution }\end{array}$} & 0.3 & Clay $(\%)$ & 0.30 & & 0.09 & 48.26 & 1 & 31.25 & 0 \\
\hline & & Total Soil Porosity (\%) & 0.10 & & 0.03 & 46.81 & 1 & 37.10 & 0 \\
\hline & & Soil Bulk Density $\left(\mathrm{gcm}^{-3}\right)$ & 0.25 & & 0.075 & 1.39 & 1 & 1.21 & 0 \\
\hline & & $\begin{array}{l}\text { Saturated Hydraulic } \\
\text { Conductivity }\left(\mathrm{cm} \mathrm{hour}^{-1}\right)\end{array}$ & 0.10 & & 0.03 & 3.65 & 1 & 2.29 & 0 \\
\hline & & $\begin{array}{l}\text { Field Capacity Soil Water } \\
\text { Content }(\%)\end{array}$ & 0.25 & & 0.075 & 17.66 & 1 & 15.73 & 0 \\
\hline \multirow{5}{*}{$\begin{array}{l}\text { Filter and } \\
\text { buffering }\end{array}$} & 0.3 & Clay (\%) & 0.15 & & 0.045 & 48.26 & 1 & 31.25 & 0 \\
\hline & & Total Soil Porosity (\%) & 0.15 & & 0.045 & 46.81 & 1 & 37.10 & 0 \\
\hline & & Total Organic Carbon (\%) & 0.25 & & 0.075 & 2.88 & 1 & 1.74 & 0 \\
\hline & & $\begin{array}{l}\text { Available Soil Water Capacity } \\
(\%)\end{array}$ & 0.30 & & 0.09 & 13.54 & 1 & 11.21 & 0 \\
\hline & & Soil Aggregate Stability Index & 0.15 & & 0.045 & 65 & 1 & 51 & 0 \\
\hline
\end{tabular}


$\mathrm{SQI}=\sum_{\mathrm{i}=1}^{\mathrm{n}} \mathrm{Wi} \times \mathrm{Si}$

Notes: SQI = Soil Quality Index, Wi $=$ Weight Index, Si $=$ Score on selected indicators. The modified soil function assessment table, weight, and soil indicators were presented in Table 1 . Soil quality criteria were presented in Table 2.

Table 2. Soil quality criteria

\begin{tabular}{|c|c|c|}
\hline No. & Soil Quality Index & Soil Quality Criteria \\
\hline 1 & $0,80-1,00$ & Very Good \\
\hline 2 & $0,60-0,79]$ & Good \\
\hline 3 & $0,40-0,59$ & Moderate \\
\hline 4 & $0,20-0,39$ & Slightly Poor \\
\hline 5 & $0,00-0,19$ & Poor \\
\hline
\end{tabular}

\section{RESULTS AND DISCUSSION}

The results showed that changes in land use types significantly affected soil physical properties observed in the study. The differences in the effect of changes in land use types on soil physical properties were presented in Table 3 and Table 4.

Table 3 shows that the high clay content and low organic matter in the land use type of maize plantation had a low aggregate stability index. This was due to the formation of a massive soil structure. The wetting process and mechanical disturbances in soil with a texture loam - clayey loam and low organic matter cause soil aggregates to break down more easily $[14,15]$. The relationship between several soil physical properties and the aggregate stability index was presented in Figure 1.

Aggregate stability and soil water holding capacity were effective parameters for studying soil quality [16]. A strong relationship between the parameters of soil physical properties and the soil aggregate stability index and available soil water capacity could be used as a basis for thinking to develop a model [17]. The relationship between several soil physical properties and available soil water capacity was presented in Figure 2.

Clay content, bulk density, porosity, hydraulic conductivity, and soil organic carbon strongly correlated with the available soil water capacity (Figure 2). The soil quality assessment model's design uses soil physical properties parameters that strongly correlate to produce a robust model $[18,19]$. The use of soil erodibility index parameters as a standard for assessing soil quality could produce an adaptive model for critical land management planning [20,21].

The soil's function to conserve biological activity in the land use type of maize plantation was $131 \%$ and $114 \%$ lower, respectively, compared to the forest and mixed plantation (Table 5).

Shallow root depth could affect the storage capacity in the land use type of maize plantation. Lack of water during the flowering period could result in loss and failure of production. The minimum tillage treatment is a better option for farmers to improve soil aggregate stability and available capacity [22]. The land function for water redistribution in mixed plantation and forest land-use types was $41 \%$ and $39 \%$ higher, respectively, compared to maize plantation (Table 6). The increasing water movement rate on the soil surface due to soil tillage could lead to increased deposition of clay particles up to a depth of $45 \mathrm{~cm}[23]$.

The initial soil water content significantly influenced the compaction process in clay textured soils. Sandy soil density did not depend on the initial soil water content but was influenced by the initial soil bulk density. The

Table 3. Some soil physical properties in mixed plantation, maize plantation and forest land use types

\begin{tabular}{|c|c|c|c|c|c|c|c|c|c|c|c|c|c|}
\hline \multirow[b]{2}{*}{$\begin{array}{l}\text { Land Use } \\
\text { Type }\end{array}$} & \multirow[b]{2}{*}{$\begin{array}{l}\text { Observation } \\
\text { Point }\end{array}$} & \multirow[b]{2}{*}{$\begin{array}{l}\mathrm{RD} \\
(\mathrm{cm})\end{array}$} & \multicolumn{3}{|c|}{ Soil Fraction } & \multirow[b]{2}{*}{$\begin{array}{c}\mathrm{BD} \\
\left(\mathrm{g} / \mathrm{cm}^{3}\right)\end{array}$} & \multirow[b]{2}{*}{$\begin{array}{l}\text { TP } \\
(\%)\end{array}$} & \multirow[b]{2}{*}{$\begin{array}{c}\mathrm{HC} \\
\text { (cm/hour) }\end{array}$} & \multirow[b]{2}{*}{$\begin{array}{l}\mathrm{OC} \\
(\%)\end{array}$} & \multirow[b]{2}{*}{ ASI } & \multirow[b]{2}{*}{$\begin{array}{l}\text { FC } \\
(\%)\end{array}$} & \multirow[b]{2}{*}{ PWP } & \multirow[b]{2}{*}{ ASWC } \\
\hline & & & $\begin{array}{c}\mathrm{S} \\
(\%)\end{array}$ & $\begin{array}{l}\mathrm{Si} \\
(\%)\end{array}$ & $\begin{array}{c}C \\
(\%)\end{array}$ & & & & & & & & \\
\hline \multirow{5}{*}{$\begin{array}{l}\text { Mixed } \\
\text { Plantation }\end{array}$} & 1 & 93 & 41.28 & 23.63 & 35.09 & 1.27 & 41.47 & 3.16 & 2.31 & 61 & 16.64 & 4.15 & 12.49 \\
\hline & 2 & 87 & 47.38 & 20.18 & 32.44 & 1.23 & 45.33 & 3.07 & 2.75 & 59 & 17.12 & 4.15 & 12.97 \\
\hline & 3 & 115 & 57.29 & 10.73 & 31.98 & 1.26 & 43.75 & 3.17 & 2.47 & 58 & 17.21 & 4.10 & 13.11 \\
\hline & 4 & 103 & 60.39 & 8.36 & 31.25 & 1.21 & 44.75 & 3.65 & 2.63 & 60 & 17.58 & 4.11 & 13.47 \\
\hline & 5 & 117 & 45.72 & 20.18 & 34.10 & 1.22 & 46.02 & 3.49 & 2.77 & 60 & 17.66 & 4.12 & 13.54 \\
\hline \multirow{5}{*}{$\begin{array}{l}\text { Maize } \\
\text { Plantation }\end{array}$} & 1 & 84 & 27.31 & 25.83 & 46.86 & 1.38 & 39.47 & 2.29 & 1.81 & 55 & 16.35 & 4.14 & 11.21 \\
\hline & 2 & 98 & 21.87 & 30.62 & 47.51 & 1.39 & 37.10 & 2.53 & 1.78 & 55 & 15.73 & 4.16 & 11.57 \\
\hline & 3 & 82 & 34.73 & 20.72 & 44.55 & 1.34 & 39.91 & 2.58 & 1.84 & 53 & 15.79 & 4.11 & 11.68 \\
\hline & 4 & 55 & 26.35 & 26.47 & 47.18 & 1.37 & 41.95 & 2.69 & 2.32 & 51 & 16.42 & 4.11 & 12.31 \\
\hline & 5 & 97 & 19.62 & 32.12 & 48.26 & 1.39 & 40.34 & 2.52 & 1.74 & 53 & 15.89 & 4.14 & 11.75 \\
\hline \multirow{5}{*}{ Forest } & 1 & 97 & 39.42 & 22.48 & 38.10 & 1.25 & 46.81 & 3.51 & 2.87 & 58 & 17.03 & 4.15 & 12.88 \\
\hline & 2 & 138 & 43.19 & 24.68 & 32.13 & 1.21 & 44.24 & 3.46 & 2.84 & 60 & 17.52 & 4.14 & 13.38 \\
\hline & 3 & 103 & 53.18 & 10.07 & 36.75 & 1.28 & 45.53 & 3.24 & 2.88 & 59 & 17.12 & 4.15 & 12.97 \\
\hline & 4 & 118 & 40.73 & 23.52 & 35.75 & 1.24 & 44.64 & 3.41 & 2.79 & 61 & 17.04 & 4.15 & 12.89 \\
\hline & 5 & 127 & 47.84 & 20.26 & 31.90 & 1.28 & 40.74 & 3.15 & 2.24 & 58 & 17.03 & 4.14 & 12.89 \\
\hline
\end{tabular}

Notes: RD = Root Depth, $\mathrm{C}=$ Clay, $\mathrm{Si}=\mathrm{Silt}, \mathrm{S}=$ Sand, BD = Bulk Density, $\mathrm{TP}=$ Total Porosity, HC = Hydraulic Conductivity, $\mathrm{OC}=$ Organic Carbon: ASI = Aggregate Stability Index, FC $=$ Field Capacity, Soil Water Content $=$ PWP $=$ Permanent Wilting Point Soil Water Content, ASWC = Available Soil Water Capacity 
Table 4. Different effects of changes in land use types on several soil physical properties

\begin{tabular}{|l|r|r|r|r|r|r|r|r|}
\hline $\begin{array}{c}\text { Land Use } \\
\text { Type }\end{array}$ & Clay & \multicolumn{1}{|c|}{$\begin{array}{c}\text { Bulk } \\
\text { Density }\end{array}$} & $\begin{array}{c}\text { Total } \\
\text { Porosity }\end{array}$ & $\begin{array}{c}\text { Hydraulic } \\
\text { Conductivity }\end{array}$ & $\begin{array}{c}\text { Carbon } \\
\text { Organic }\end{array}$ & $\begin{array}{c}\text { Aggregate } \\
\text { Stability }\end{array}$ & $\begin{array}{c}\text { Capacity } \\
\text { Water } \\
\text { Content }\end{array}$ & $\begin{array}{c}\text { Available } \\
\text { Soil Water } \\
\text { Capacity }\end{array}$ \\
\hline $\begin{array}{l}\text { Mixed } \\
\text { Plantation }\end{array}$ & $32.97^{\mathrm{a}}$ & $1.24^{\mathrm{a}}$ & $44.26^{\mathrm{b}}$ & $3.31^{\mathrm{b}}$ & $2.59^{\mathrm{b}}$ & $59.6^{\mathrm{b}}$ & $17.24^{\mathrm{b}}$ & $13.12^{\mathrm{b}}$ \\
\hline $\begin{array}{l}\text { Maize } \\
\text { Plantation }\end{array}$ & $46.87^{\mathrm{b}}$ & $1.37^{\mathrm{b}}$ & $39.75^{\mathrm{a}}$ & $2.52^{\mathrm{a}}$ & $1.90^{\mathrm{a}}$ & $53.4^{\mathrm{a}}$ & $16.04^{\mathrm{a}}$ & $11.86^{\mathrm{a}}$ \\
\hline Forest & $34.93^{\mathrm{a}}$ & $1.25^{\mathrm{a}}$ & $44.39^{\mathrm{b}}$ & $3.35^{\mathrm{b}}$ & $2.72^{\mathrm{b}}$ & $59.2^{\mathrm{b}}$ & $17.15^{\mathrm{b}}$ & $13.00^{\mathrm{b}}$ \\
\hline
\end{tabular}

The numbers followed by different letters shown significant differences according to the Duncan multiple range test $(\alpha: 0.05)$

increase in bulk density in clay soil caused an increase in the formation of micro pore spaces. Soil hydraulic conductivity decreases with increasing micropore space volume [24].

Organic carbon and available soil water capacity were parameters that play an important role in influencing soil as a filter and buffer. Changes in land use from forest to mixed plantation and maize plantation caused changes in the soil function index as filter and buffer by $4 \%$ and $108 \%$, respectively (Table 7 ). Organic carbon and available soil water capacity had an

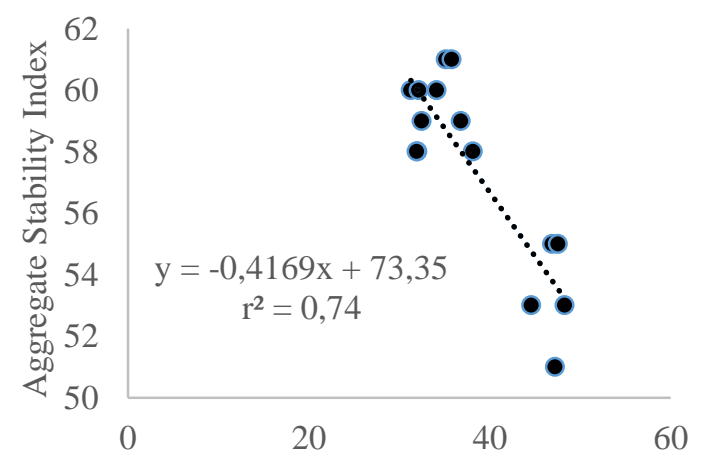

(a) Clay (\%)

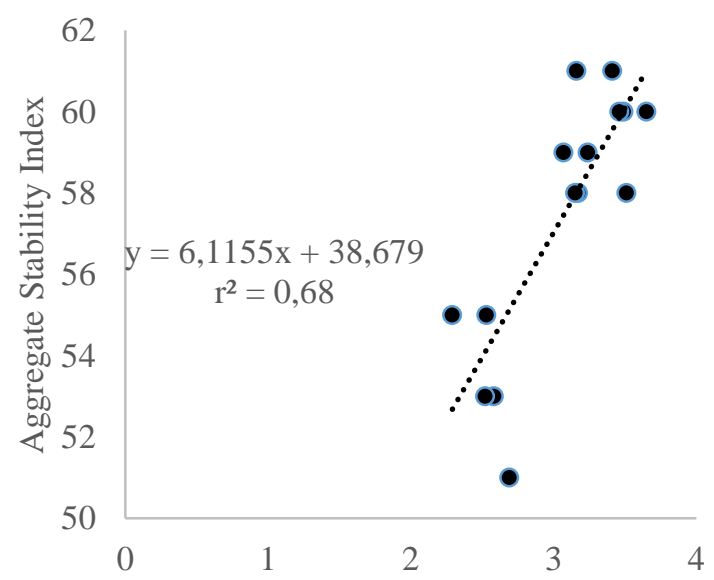

(c) Hydraulic Conductivity $\left(\mathrm{cm} \mathrm{hour}^{-1}\right)$ important role in maintaining the soil's function as a filter and buffer. High soil organic carbon in forest and mixed plantation land uses caused the index of soil function as a filter and buffer higher than maize plantation. Intensive tillage practices could lead to the decreased organic carbon content in the land use type of maize plantation. Soil tillage had a strong influence on the decomposition of organic carbon at the soil surface. Soil organic carbon fell by up to $37 \%$ in intensive tillage treatments $[25,26]$. On the other hand, organic carbon increases in the left undisturbed land in the long term $[27,28]$.

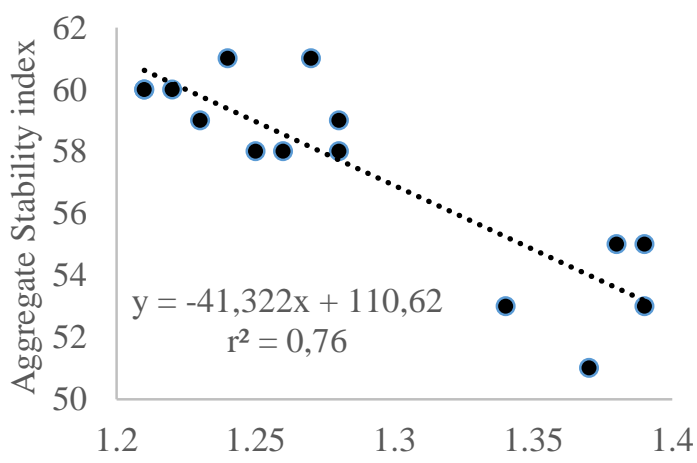

(b) Bulk Density $\left(\mathrm{mg} \mathrm{cm}^{-3}\right)$

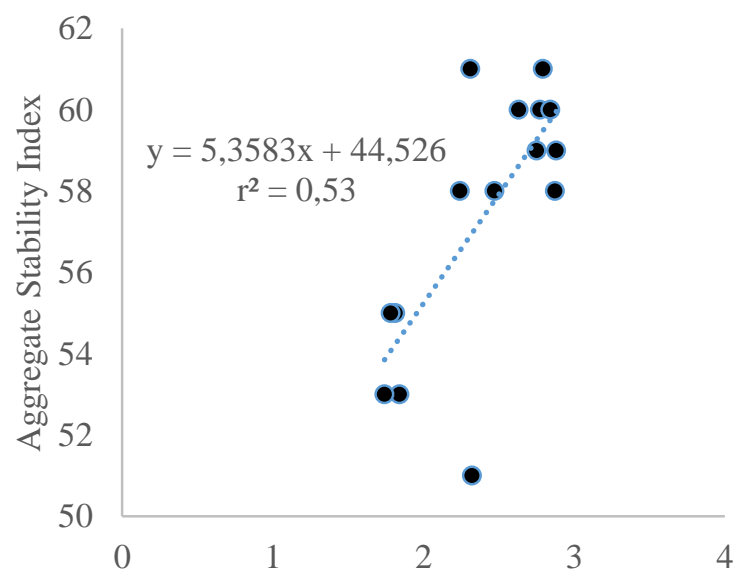

(d) Carbon Organic (\%)

Figure 1 Relationship between clay content (a), soil bulk density (b), hydraulic conductivity saturated (c) organic carbon (d) and soil aggregate stability 


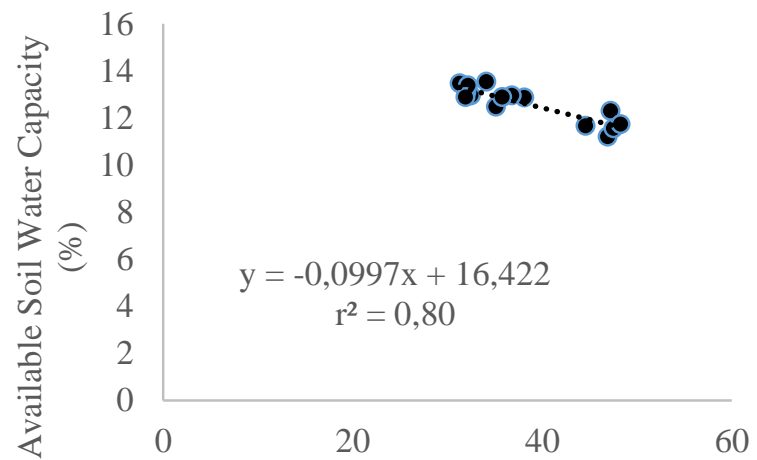

(a) Clay (\%)

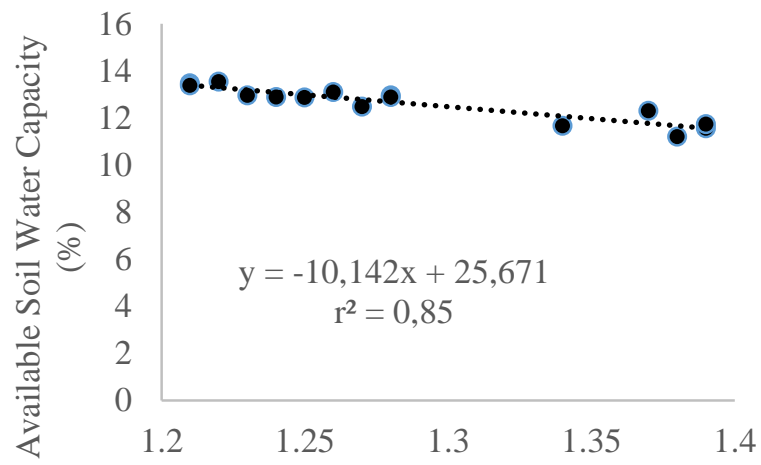

(b) Bulk Density $\left(\mathrm{g} \mathrm{cm}^{-3}\right)$

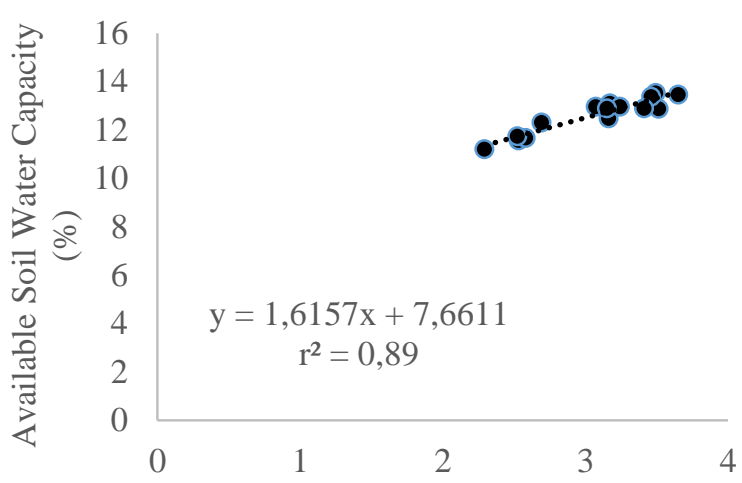

(d) Hydraulic Conductivity ( $\mathrm{cm}$ hour ${ }^{-1}$ )

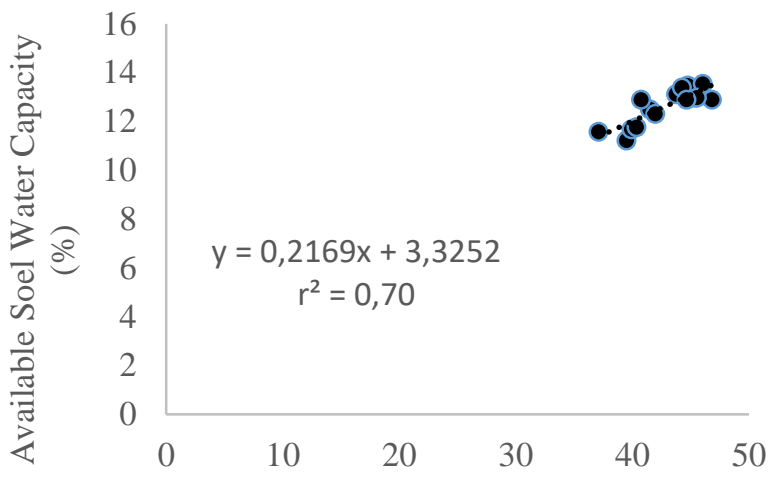

(c) Soil Porosity (\%)

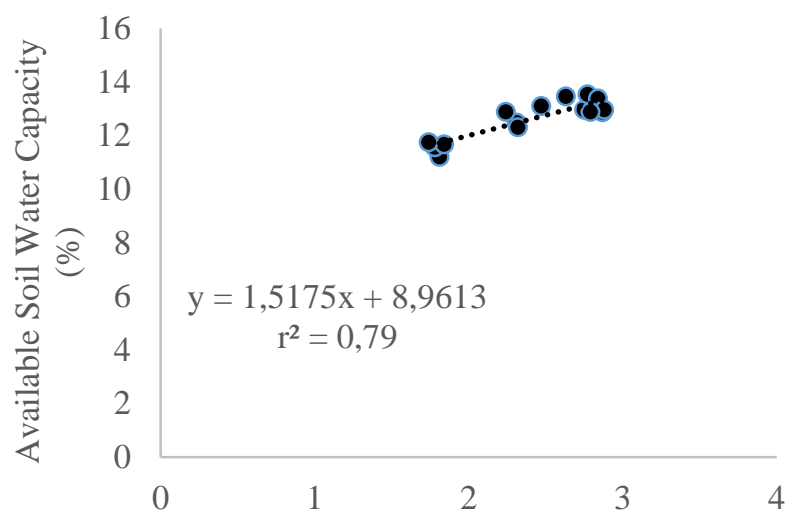

(e) Total Organic Carbon (\%)

Figure 2 The relationship between clay (a), bulk density (b), total porosity (c) Saturated hydraulic conductivity, (d) organic carbon, (e) and available soil water capacity

The change in land use from forest to mixed plantation did not cause a change in the soil quality index. On the other hand, land use for maize plantation had caused the soil quality index to drop by up to $89 \%$. The soil quality criteria for maize plantation land-use types were quite poor (Table 8). The burning of crop residues and plant litter was a major factor that causes the loss of organic carbon in agricultural land. Organic carbon stocks in the 12 years old cocoa land use type with an agroforestry pattern had not fully met conservation farming needs. Soil erosion in the cocoa land use type was still higher than tolerable soil erosion [29,30].

Soil physical properties that predominantly affected changes in soil quality could not be identified in this study. The development of further research related to soil erodibility would be very useful for developing a soil quality assessment model on degraded land [31,32]. 
Table 5. Soil quality index based on soil function to conserve biological activity

\begin{tabular}{|l|c|c|c|}
\hline \multicolumn{2}{|c|}{ Assesment Indicators } & \multicolumn{2}{c|}{ Land Use Types } \\
\cline { 2 - 4 } & Mixed Plantation & Maize Plantation & Forest \\
\hline Root Medium & & & 0.0881 \\
\hline Root depth & 0.0686 & 0.0403 & 0.0620 \\
\hline Bulk density & 0.0680 & 0.0100 & 0.0302 \\
\hline Soil Humidity & & & 0.0526 \\
\hline Total soil porosity & 0.0296 & 0.0109 & 0.0064 \\
\hline Total organic carbon & 0.0458 & 0.0228 & 0.0462 \\
\hline Clay & 0.0029 & 0.0270 & 0.2855 \\
\hline Available soil water Capacity & 0.0492 & 0.0126 & 0.1236 \\
\hline Total & 0.2641 & & 0.20 \\
\hline
\end{tabular}

Table 6. Soil quality index based on the soil water redistribution function

\begin{tabular}{|l|c|c|c|}
\hline \multirow{2}{*}{ Assesment Indicators } & \multicolumn{3}{c|}{ Land Use Types } \\
\cline { 2 - 4 } & Mixed Plantation & Maize Plantation & Forest \\
\hline Clay & 0.0100 & 0.0800 & 0.0180 \\
\hline Total soil porosity & 0.0220 & 0.0125 & 0.0220 \\
\hline Soil bulk density & 0.0640 & 0.0100 & 0.0600 \\
\hline Saturated hydraulic conductivity & 0.0240 & 0.0100 & 0.0240 \\
\hline Field capacity soil water content & 0.0600 & 0.0150 & 0.0540 \\
\hline Total & 0.1800 & 0.1275 & 0.1780 \\
\hline
\end{tabular}

Table 7. Soil quality index analysis based on soil function as filter and buffer

\begin{tabular}{|l|c|c|c|}
\hline \multirow{2}{*}{ Assesment Indicators } & \multicolumn{3}{c|}{ Land Use Types } \\
\cline { 2 - 4 } & Maize & Maize & 0.0096 \\
\hline Clay & 0.0055 & 0.0405 & 0.0302 \\
\hline Total soil porosity & 0.0296 & 0.0136 & 0.0689 \\
\hline Total organic carbon & 0.0760 & 0.0135 & 0.0693 \\
\hline Available soil water capacity & 0.0738 & 0.0236 & 0.0175 \\
\hline Soil aggregate stability & 0.0184 & 0.0063 & 0.1955 \\
\hline Total & 0.2033 & 0.0975 & \\
\hline
\end{tabular}

Table 8. Soil quality criteria for mixed plantation, maize plantation and forest land use types

\begin{tabular}{|c|c|c|}
\hline Land Use Type & Soil Quality Index & Criteria \\
\hline Mixed Plantation & 0.6474 & Good \\
\hline Maize Plantation & 0.3486 & Quite poor \\
\hline Forest & 0.6590 & Good \\
\hline
\end{tabular}

\section{CONCLUSION}

Changes in land-use types from forest to maize plantation had a significant effect on soil physical properties. However, soil physical properties in mixed plantation land-use types were not significantly different from the forest. The soil quality index for forest land use, mixed plantation, and maize plantation were classified as good (0.6590), good (0.6474), and somewhat poor (0.3486).

The use of aggregate stability index parameters and available soil water capacity could develop a soil quality assessment model for degraded land. However, it had a weakness that it could not explain the relationship between the soil's physical properties, which was influenced by the surface soil erosion process.
Further research based on soil erodibility parameters would be very useful for developing critical land management models. The implication of this study's results was the formulation of an adaptive soil quality assessment model to develop a critical land management policy design in the Palu watershed.

\section{ACKNOWLEDGMENTS}

The authors would like to thank the Dean of the Agriculture Faculty, Tadulako University, and the staff for using the laboratory facilities.

\section{REFERENCES}

[1] S. Darman, M. N. Ali, M. Basir-Cyio, A. Anshary, M. Rusydi, J. Mohamed, M. R. Razman, The land biophysical degradation and community traumatic 
condition due to the periodic flooding in Miu Watershed Central Sulawesi, Indonesia. Journal of Food, Agriculture \& Environment, 15(3/4), 2017, pp. 123-129.

[2] S. A. Hwang, S. J. Hwang, S. R. Park, S. W. Lee, Examining the relationships between watershed urban land use and stream water quality using linear and generalized additive models, Water, 8(4), 2016, pp. 155.

[3] Y. W. Zhang, Z. P. Shangguan, The change of soil water storage in three land-use types after ten years on the Loess Plateau, Catena, 147, 2016, pp. 87-95.

[4] D. Assefa, B. Rewald, H. Sandén, C. Rosinger, A. Abiyu, B. Yitaferu, D. L. Godbold, Deforestation and land use strongly affect soil organic carbon and nitrogen stock in Northwest Ethiopia, Catena, 153, 2017, pp. 89-99.

[5] V. L. Puerta, E. I. P. Pereira, R. Wittwer, M. Van Der Heijden, J. Six, Improvement of soil structure through organic crop management, conservation tillage, and grass-clover ley, Soil and Tillage Research, 180, 2018, pp. 1-9.

[6] D. Widjajanto, U. Hasanah, Land resource management strategy for the sustainability of the upper watershed of Palu (a case study of Miu sub watershed in Sigi regency), Agroland: The Agricultural Sciences Journal, 6(1), 2019, pp. 3443.

[7] D. Widjajanto, R. Gailea, Kajian pengembangan agroforestri untuk pengelolaan daerah aliran sungai Toranda, Kecamatan Palolo, Kabupaten Sigi, Propinsi Sulawesi Tengah, Agroland: Jurnal Ilmuilmu Pertanian, 15(4), 2008, pp. 264 - 270

[8] S. V. Archontoulis, I. Huber, F. E. Miguez, P. J. Thorburn, N. Rogovska, D. A. Laird, A model for mechanistic and system assessments of biochar effects on soils and crops and trade-offs, Gcb Bioenergy, 8(6), 2016, pp. 1028-1045.

[9] R. P. Dick, Soil enzyme activities as indicators of soil quality, Defining soil quality for a sustainable environment, 35, 1994, pp. 107-124.

[10] S. Pagiu, T. I. B. Ramlan, Y. S. Patadungan, Land Index and Production of Arabica Coffee (Coffea arabica L.) in Smallholding Plantation Tana Toraja District, Indonesia, Journal, 15(4), 2020, pp. 587592. DOI: http://iieta. org/journals/ijdne

[11] A. Thomazini, E. S. Mendonça, I. M. Cardoso, M. L. Garbin, SOC dynamics and soil quality index of agroforestry systems in the Atlantic rainforest of Brazil, Geoderma Regional, 5, 2015, pp. 15-24.
[12] H.D. Weissmannová, J. Pavlovský, Indices of soil contamination by heavy metals - methodology of calculation for pollution assessment (minireview), Environmental Monitoring and Assessment 189(12), 2017, pp. 1-25.

[13] Z.J. Liu, W. Zhou, J.B. Shen, S. . Li, G.Q. Liang, X.B. Wang, C. Ai, et al., Soil quality assessment of acid sulfate paddy soils with different productivities in Guangdong Province, China, Journal of Integrative Agriculture, 1(13), 2014, pp. 177-186.

[14] C. Pituello, N. Dal Ferro, O. Francioso, G. Simonetti, A. Berti, I. Piccoli, F. Morari, et al., Effects of biochar on the dynamics of aggregate stability in clay and sandy loam soils, European Journal of Soil Science, 69(5), 2018, pp. 827-842.

[15] X. Wu, Y. Wei, J. Wang, D. Wang, L. She, J. Wang, C. Cai, Effects of soil physicochemical properties on aggregate stability along a weathering gradient, Catena, 156, 2017, pp. 205215.

[16] L. Salvati, A. Colantoni, Land use dynamics and soil quality in agro-forest systems: A country-scale assessment in Italy, Journal of Environmental Planning and Management, 58(1), 2015, pp. 175188.

[17] A. C. C. Ferreira, L. F. C. Leite, A. S. F. de Araújo, N. Eisenhauer, Land-use type effects on soil organic carbon and microbial properties in a semiarid region of northeast Brazil, Land Degradation and Development, 27(2), 2016, pp. 171-178.

[18] E. Rabot, M. Wiesmeier, S. Schlüter, H. J. Vogel, Soil structure as an indicator of soil functions: a review. Geoderma, 314, 2018, pp.122-137.

[19] M. Naderi-Boldaji, T. Keller, Degree of soil compactness was highly correlated with the soil physical quality index $\mathrm{S}$, Soil and Tillage Research, 159, 2016, pp. 41-46.

[20] V. de Paul Obade, R. Lal, A standardized soil quality index for diverse field conditions, Science of the total environment, 541, 2016, pp. 424-434.

[21] J. G. Rangel-Peraza, E. Padilla-Gasca, R. LópezCorrales, J. R. Medina, Y. Bustos-Terrones, L. E. Amabilis-Sosa, T. Osuna-Enciso at al., Robust Soil Quality Index for Tropical Soils Influenced by Agricultural Activities, Journal of Agricultural Chemistry and Environment, 6(04), 2017, pp. 199221.

[22] H.M. Salem, C. Valero, M. Á. Muñoz, M. G. Rodríguez, L. L. Silva, Short-term effects of four 
tillage practices on soil physical properties, soil water potential, and maize plantation, Geoderma, 237, 2015, pp. 60-70.

[23] B. Badalíková, Influence of soil tillage on soil compaction, In Soil Engineering, Springer, Berlin, Heidelberg, 2010, pp. 19-30.

[24] K. Saffih-Hdadi, P. Défossez, G. Richard, Y. J. Cui, A. M. Tang, V. Chaplain, A method for predicting soil susceptibility to the compaction of surface layers as a function of water content and bulk density, Soil and Tillage Research, 105(1), 2009, pp. 96-103.

[25] B.F. Brockett, C.E. Prescott, S.J. Grayston, Soil moisture was the major factor influencing microbial community structure and enzyme activities across seven biogeoclimatic zones in western Canada, Soil biology and biochemistry, 44(1), 2012, pp. 9-20.

[26] V. Kabiri, F. Raiesi, M. A. Ghazavi, Tillage effects on soil microbial biomass, SOM mineralization and enzyme activity in a semiarid Calcixerepts. Agriculture, Ecosystems \& Environment, 232, 2016, pp. 73-84.

[27] E. K. Bünemann, G. Bongiorno, Z. Bai, R. E. Creamer, G. De Deyn, R. de Goede, M. Pulleman, et al., Soil quality-A critical review, Soil Biology and Biochemistry, 120, 2018, pp. 105-125.

[28] M. Burdukovskii, I. Kiseleva, P. Perepelkina, Y. Kosheleva, Impact of different fallow durations on soil aggregate structure and humus status parameters, Soil and Water Research, 15(1), 2019, $1-8$.

[29] A. Monde, Degradasi stok karbon (C) akibat alih guna lahan hutan menjadi lahan kakao di Das Nopu, Sulawesi Tengah, Agroland: Jurnal Ilmuilmu Pertanian, 16(2), 2009, pp. 110-117.

[30] A. Monde, N. Sinukaban, K. Murtilaksono, N. Pandjaitan, Dinamika karbon (C) akibat alih guna lahan hutan menjadi lahan pertanian. Agroland: Jurnal Ilmu-ilmu Pertanian, 15(1), 2008, pp. 22-26.

[31] F. Raiesi, A minimum data set and soil quality index to quantify the effect of land use conversion on soil quality and degradation in native rangelands of upland arid and semiarid regions, Ecological Indicators, 75, 2017, pp. 307-320.

[32] F. Santos-Francés, A. Martínez-Graña, C. ÁvilaZarza, M. Criado, Y. Sánchez, Comparison of methods for evaluating soil quality of semiarid ecosystem and evaluation of the effects of physicochemical properties and factor soil erodibility
(Northern Plateau, Spain), Geoderma, 354, 2019, pp. 113872. 